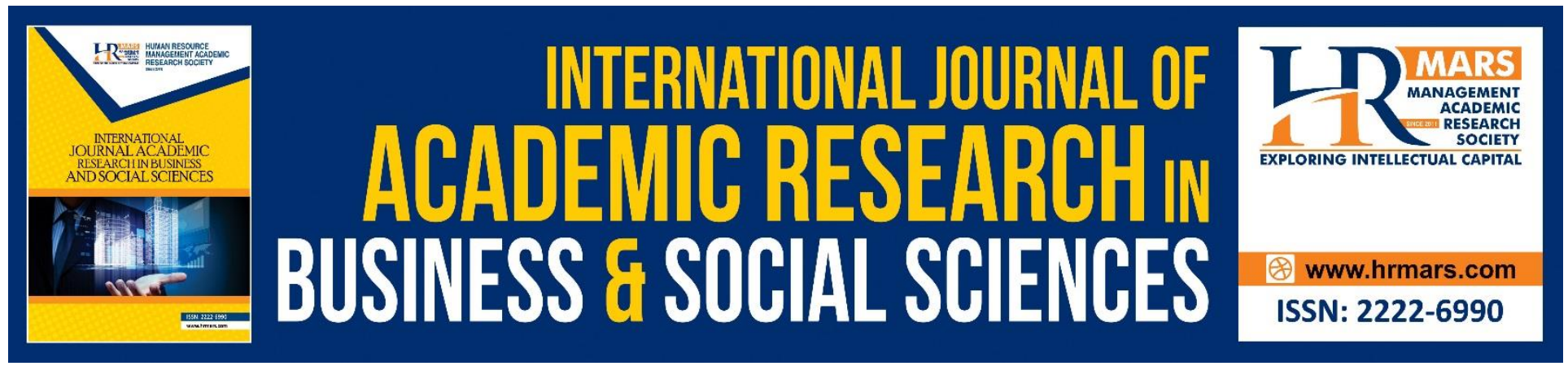

\title{
Ethical Education Haji Abdullah Idris
}

\author{
Mohamed M.L., Omar S.H.S., Abdullah W.I.W, Musa R., Mustafa M.F., \\ Abdelgelil M.F.M.
}

To Link this Article: http://dx.doi.org/10.6007/IJARBSS/v8-i10/4714

DOI: $10.6007 /$ IJARBSS/v8-i10/4714

Received: 21 Sept 2018, Revised: 19 Oct 2018, Accepted: 26 Oct 2018

Published Online: 30 October 2018

In-Text Citation: (Mohamed et al., 2018)

To Cite this Article: Mohamed, M. L., Omar, S. H. S., Abdullah, W. I. ., Musa, R., Mustafa, M. F., \& Abdelgelil, M. F. M. (2018). Ethical Education Haji Abdullah Idris. International Journal of Academic Research in Business and Social Sciences, 8(10), 84-90.

Copyright: (C) 2018 The Author(s)

Published by Human Resource Management Academic Research Society (www.hrmars.com)

This article is published under the Creative Commons Attribution (CC BY 4.0) license. Anyone may reproduce, distribute, translate and create derivative works of this article (for both commercial and non-commercial purposes), subject to full attribution to the original publication and authors. The full terms of this license may be seen

at: http://creativecommons.org/licences/by/4.0/legalcode

Vol. 8, No. 10, 2018, Pg. 84 - 90

http://hrmars.com/index.php/pages/detail/IJARBSS

JOURNAL HOMEPAGE

Full Terms \& Conditions of access and use can be found at http://hrmars.com/index.php/pages/detail/publication-ethics 


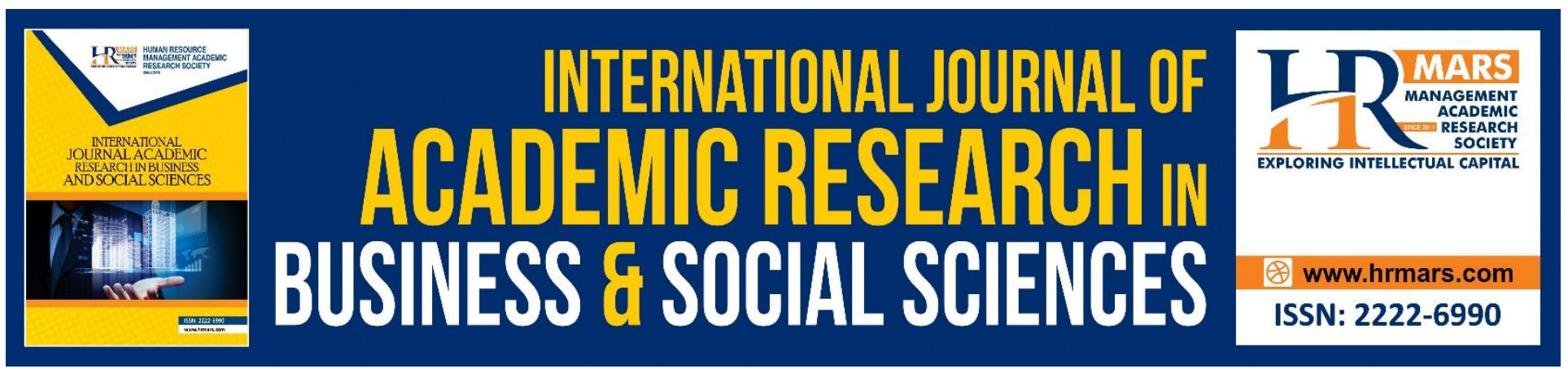

\title{
Ethical Education Haji Abdullah Idris
}

\author{
Mohamed M.L. ${ }^{1}$, Omar S.H.S..$^{*}$, Abdullah W.I.W ${ }^{3}$, Musa R. ${ }^{4}$, Mustafa \\ M.F. ${ }^{5}$, Abdelgelil M.F.M. ${ }^{6}$ \\ ${ }^{2}$ Institute of Islamic Product Research and Islamic Civilization, Universiti Sultan Zainal Abidin, \\ Malaysia. \\ ${ }^{3}$ Center for Industrial and Community Networking, Universiti Sultan Zainal Abidin, Malaysia. \\ 4,5,6 Faculty Of Islamic Contemporary Studies, Universiti Sultan Zainal Abidin, Malaysia. \\ *Corresponding Author : sylutfi@unisza.edu.my
}

\begin{abstract}
Sufism was long established in Kelantan before Tuan Tabal (1840-1894) began actively spreading the Ahmadiyyah order in Kota Bharu in the 1870s. So, when it comes to the question of the presence of tarekat in the land of Kelantan then it refers to the Ahmadiyya Sufis order as Negeri Sembilan because in both states only the order of Ahmadiyya is found wide-ranging. This article will discuss another Ahmadiyya successor in the State of Kelantan, he is a student of Haji Abdullah Idris and the legacy of Sidi Muhammad Azahari. This article will focus on the teaching of spiritual education Haji Abdullah Idris. This qualitative study uses data collection and data analysis methods. To obtain accurate data of library methods and interviews have been used. The results of the study analysis are divided into three main thrusts, the first personal motivation of the character, the eminent figure, the essence of the life of Haji Abdullah Idris. Hopefully this study will attract students and pave the way for researchers and other historians to explore in greater depth the various information related to Haji Abdullah Idris and the Kelantan Ahmadiyya Sufis order.
\end{abstract}

Keywords: Teaching, Spirituality, Ahmadiyya Order, Haji Abdullah Idris

\section{INTRODUCTION}

The Ahmadiyya is the sole Sufis order which is widespread in the state of Kelantan. This article will highlight the teachings of spiritual education of Haji Abdullah Idris as the driver of the Ahmadiyya Sufis order in the state of Kelantan. In the environment of Sufism and the Ahmadiyya that has grown, Haji Abdullah Idris increased the age of adolescents. This is in line with Kota Bharu's urban situation is growing rapidly as a well-known cottage center and being the centerpiece of students from all over the Malay World. As a precursor to this article explain the biography of Haji Abdullah Idris briefly. His full name is Haji Abdullah bin Haji Idris bin Haji Noh was born in Kampung Gajah Mati, Kota Bahru Kelantan in $1909 \mathrm{M}$. He is the third of six siblings (Abdullah, 2017). His early education at Padang 
Garong Malay School, then to Religious School of Muhammadiyah. Then proceed to Pondok Tok Khatib Haji Nik Abdullah Haji Abdul Samad, then Pondok Haji Ahmad Hakim Abdul Manan in Kubang Pasu and finally Pondok Haji Yaakub Haji Ahmad in Lorong Gajah Mati Kota Bahru Kelantan (Abdullah, 2017).

After completing his studies, he was elected as Assistant Minister of Kelantan Dato 'Prime Minister Nik Mahmud Ismail (1880-1964) in 1928. The experience of working with the Chief Minister of Kelantan had exposed him to various government intrigues, understanding the British colonies, listening to critics and analysis of local and international political rallies, listening to the criticisms of the Malay leaders, and figures of Malay scholars. His sweet experience with Dato 'Perdana was to produce a book titled "Citra Kelantan" in 1933, which was a measure of learning at Kelantan Schools (Abdullah, 2017). In 1933 he decided to quit because he did not want to be tied to a particular party. Then he ventured into the field of timber company by owning three factory buildings located at Kampung Atas Paloh Kota Bharu. In 1948 his woodworker was involved with the fire, so he decided not to re-develop the timber plant because he wanted to concentrate on the life that was stuck until the end of his life (Abdullah, 2017).

He was ordered by Sidi Muhammad Azahari when he was 16 years old and was given a personal robe by Sidi Muhammad Azahari and was given a call (anthijal) of the true man according to the interpretation of his teacher (Abdullah, 2017). His involvement as an Ahmadiyya successor after his marriage in 1934 guided the Ahmadiyya Sufis order group at Surau Haji Abdus Salam in Kampung Kubang Pasu Kota Bharu. Followers and practitioners of tarekat mostly come from around Kota Bahru, Kampung Laut, Kuala Krai and Southern Thailand (Abdullah, 2017). He and his brother-in-law (Yahya Abdus Salam) produced a small pamphlet, "Awrad al-Awlia was published and distributed free by the Kelantan Islamic Religious Affairs Department with verification confirmation by Kelantan Deputy Mufti, Haji Ismail Yusuf in 1988 (Yahya, 1988). At the time of his demise on October 4, 1994, he continued serving those who visited him for asking him related to spiritual guidance and the Ahmadiyya Sufis order (Mahmud, 2017).

\section{METHODOLOGY}

This qualitative study uses data collection and data analysis methods. Data collection methods through libraries and special interviews with families and previous research figures were conducted to obtain information on the biography of the characters and as the driving force of the Ahmadiyya Sufis path in Kelantan.

\section{RESULTS AND DISCUSSIONS}

\section{Teaching of spiritual education Haji Abdullah Idris}

The result of analysis from the data obtained concludes that based on the spiritual path, Haji Abdullah Idris has been able to elevate the superiority of the heart as its center of identity. His devotion and istiqamah in preserving the application of the heart of the Divine nurse, has been able to protect himself despite being subjected to various material examinations. He was exposed to various temptations and glory while accompanying a state executive and luxury while enjoying life as an entrepreneur. The ability of Haji Abdullah Idris to defend himself as a scholar who is able to 
INTERNATIONAL JOURNAL OF ACADEMIC RESEARCH IN BUSINESS AND SOCIAL SCIENCES

Vol. 8, No. 10, Oct. 2018, E-ISSN: 2222-6990 @ 2018 HRMARS

maintain his momentum to remain on the spiritual path despite being forced to cross the various obstacles that can divert him from the track is a great achievement to be learning and teaching.

\section{Personal Drivers Haji Abdullah Idris \\ i) Environment and Family}

As a person who has a high inclination to become a follower and practitioner of the Ahmadiyya, the growth of the personality of Haji Abdullah Idris as a practitioner and transporter of the transcripts runs in a harmonious process. Since his childhood, he has been exposed to a vibrant environment of religious variations because his residence is busy and huffy with the voice of the students reading the Holy Quran under the guidance of his mother. In addition, his father's life was seen to be a lot of alms and ceremonies after a business deal with the kitchen. It is the environment that instills the seeds of his personal tendency to approach and deepen the world of Sufism and engage in the activities of tarekat although his personality is different from his relatively quiet father.

\section{ii) Sidi Muhammad al-Azahari}

Subsequently, an important impetus that pinned his commitment to his life was his encounter with Sidi Muhammad Azahari in Kuala Terengganu in 1925. It was a historic visit to Haji Haji Idris for his personal encounter with a prominent leader of the Ahmadiyya who was highly praised by many followers in Kelantan and Terengganu. The experience of this meeting was very meaningful when he was presented with a robe and was called by the anta al-Rijal by Sidi Muhammad Azahari in front of his teacher, Tok Khatib Haji Nik Abdullah on a visit to Kuala Terengganu. The gift of a robe is very symbolic of its meaning because it is a sign of respect for a syeikh tarekat to a follower. It turns out here Sidi Muhammad Azahari has been able to tackle the spiritual potential of this teenager. This event is an important transition point that implements confidence and implements commitment to continue to hold fast to the life of the enemy and determined to follow the path further in the course of journey as one of the founders of spiritual knowledge (al-salikin) and to live the divine knowledge authentic (Abdullah, 2017).

\section{iii) Haji Yaakub Ahmad}

In pursuit of sciences of Sufism, he considers Hajj Yaakub Ahmad as a teacher who gives a lot of guidance (mursyid) in exploring, understanding and appreciating the divine secrets in achieving the essence and makrifat besides empowering the character by adorning himself with the praiseworthy character and away from the ungodly. The long-standing opportunity accompanied by his teacher, Haji Yaakub Ahmad who was known for his many attributes of moral virtues that embraced his personality, had a profound spiritual impetus to the enhancement of identity of Haji Abdullah Idris. This teacher always opens a comfortable space for his beloved pupils to ask and share experiences at any time about the various spiritual turmoil and spiritual silence that a settler (al-salik) passes through the various stages of spiritual journey and from the process of transforming spiritual experiences (Mahmud, 2017). The levels of sharing of spiritual experience experienced with the guidance of his murshid teacher greatly infiltrate into the depths of his heart and inject the spiritual food that is very effective in the formation of his identity. 


\section{Exemplary Person}

Haji Abdullah Idris does not take a stand on the responsibility of society and the state. In the busyness of focusing on the routine of practicing a tarekat practitioner and commander of the Ahmadiyya, he still provides space for his social responsibility duties. Here is the essence of teaching from the practice and the holdings of renowned Sufi who guide in his spiritual life as a sufi example of:

\section{i) Zul-Nun al-Masri}

Haji Abdullah Idris often prompts Zul-Nun al-Masri's counsels to family members and the Ahmadiyya's disciples not to be complacent with the temptations of the world and to emphasize the necessity of solitude to the following four pillars:

- Do not associate with Allah except with obedience to all His commandments (muwafaqah).

- Do not associate with man except with practice the attitude of one another (munasahah).

- Do not mingle with lusts but with opposed to all temptations and desires (mukhalafah).

- Do not associate with the devil except by virtue fighting against all sedition and evil (muharabah).

\section{ii) Hassan al-Basri}

With regard to the importance and need to be alert in everyday life, conversations and interactions so that they are not drifting are drifting to the point of appetite and devotion to demons and to prioritize ego and self-interest. He often reveals the advice and reminder of Hassan al-Basri which means "How can I not be afraid and grieved at all times while Allah SWT always sees what I do". Sometimes when pronouncing these words, tears of Haji Abdullah Idris filled his eyelids and bowed in silence as he was silent (Abdullah, 2017).

\section{iii) Rabi'at al-'Adawiyah}

The atmosphere of the spiritual life of Haji Abdullah Idris who is often covered with alertness mixed with displeasure with the doctrine of khauful-Lah has been cured and cooled by the doctrine of divine love (al-hubbul-divine) which became the famous Sufi holdings, Rabi'at al-'Adawiyah. He often sparked the advantages of al-hubbul-divine doctrine in the presence of his immediate family and a handful of his followers so as not to be misinterpreted and not to be misled as something strange and elusive and appreciated. Because the doctrine recommended by Rabi'at al-Adawiyah is more meaningful in love in the strictest sense and in the obedience of the Creator's commands and away from His rejection. In addition, always extend his praise to Him, extolling His holiness (al-taqdis) and seeking forgiveness from Him for fear of being far from His sight (Abdullah, 2017).

\section{iv) Abu Hussain al-Nuri}

As for the visitors and the lost of guidance and the mistakes and ambiguities in their focus as practitioners of tasawuf and followers of tarekat who are more focused on the aspects of worship, remembrance and wirid tarekat. He often reminded them of the advice of a renowned Sufi, Abu Hussain al-Nuri who reminded him that the Sufism was not the effects of the painting and not of various knowledge but it was the character. For Hajj Abdullah Idris the remembrance of al-Nuri is 
INTERNATIONAL JOURNAL OF ACADEMIC RESEARCH IN BUSINESS AND SOCIAL SCIENCES Vol. 8, No. 10, Oct. 2018, E-ISSN: 2222-6990 @ 2018 HRMARS

very implicit in its meaning as it attempts to draw attention to the need to accommodate all the accomplish of dhikr and worship with the priority of the principle of self-purification of the finest properties and thereby replacing it with adornment with the noble qualities (Abdullah, 2017).

\section{v) Ahmad bin Idris}

Most of his life focuses on spiritual life, Haji Abdullah Idris's lips are not lonely from pouring out the gratefulness of being given the opportunity to practice the Ahmadiyah order. His sense of indebtedness and his sense of belonging to the blessings of spiritual guidance Sidi Ahmad Idris. This is clearly reflected in his tongue that often reveals the words in front of the children, his family members and his closest pupil that says "With the blessing of the Prophet and Sidi Ahmad" every time a difficult problem is overwritten including pain or seeking something lost even when hearing good news about the achievement of family members. At this time, he also often practiced dhikr "Ya Latif" alone or with his wife when it arises a difficulty or anxiety. This practice of dhikr, which reaches the tens of thousands will be perfected by several times the "Ya Latif" prayer contained in the Awrad al-Awlia pamphlet. The same thing is done by his grandchildren and has become a tradition in the family of Haji Abdulah Idris when overtaken by a difficult problem will gather read Zikir Ya Latif en masse and be alone to get calm, ease the annoyance and strengthen faith in finding solutions to the problems encountered (Abdullah, 2017).

\section{The Essence of The People's Life}

If thought deeply, the humble and courageous stance of Haji Abdullah Idris from the beginning in fulfilling his wishes and dreams to remain istiqamah on the spiritual path is evident from the daring attitude of leaving his career as assistant Dato 'Perdana who can guarantee life more comfortably in the future. After entering the household of the world, Haji Abdullah Idris has come across numerous challenges in the form of luxury tests and hardships in life. On the advice of his teacher and the strength of the spiritual bull that had been planted in his heart, Haji Abdullah Idris was able to deal with the various temptations of greatness and greatness and to continue serving in the life of the believer. Using the occasion of the night he remained istiqamah in fulfilling the obligations of a followers of tarekat to draw close to Allah through the practice of circumcision and remembrance.

His stance is also influenced by personal experience of seeing the behavior of many human beings haunted for the pursuit of wealth and greatness of the world. This was his experience when he was in charge of Kelantan Minister, Dato 'Perdana Nik Mahmud Ismail. From here he was able to see the various human beings who were drifting towards materialism and how to divide the life of the world brought great power to the extinction of faith and deviation of acting sanity. All this is a lesson and a lesson to him in determining his own way of life, especially the attitude of being free and not tied to any position that can extend his identity from the spiritual axis (Abdullah, 2017).

When he is thought to be able to surpass a variety of potential tests he can divert his heart from the spiritual axis. This enslaved himself as a model sufi. Armed with experience from various angles of the environment he pursued, he was able to stand up to maintain his identity as a selfesteemed person because he was preserved with the spiritual roots that had grown deeper since his youth. The various dimensions of the environment from the realm of education and the nature of his natural work and business turned out to be a conducive ingredient in enhancing his identity as a Sufi. 
INTERNATIONAL JOURNAL OF ACADEMIC RESEARCH IN BUSINESS AND SOCIAL SCIENCES

Vol. 8, No. 10, Oct. 2018, E-ISSN: 2222-6990 ㄷ 2018 HRMARS

\section{CONCLUSION}

Haji Abdullah Idris was able to stand up to maintain his identity as a self-esteemed person because he was kept in the spirit of embedded spiritual roots deeper than ever since his teenage years. He did not slip from the spiritual foundation due to the various transitions of life that followed him. As a Sufis who always practice, Haji Abdullah Idris was able to preserve openness in socializing as long as it does not neglect parallel with the spirit of Islamic teachings. Indeed, from a relatively long and windy spiritual journey it is clearly expressed and implied by the various dimensions of the skill and the identity of the self-adorned with a sense of individuality that can be used and guided by life.

\section{ACKNOWLEDGEMENT}

This article is part of a research fund sponsored and managed by the Center for Research and Innovation (RMIC), Sultan Zainal Abidin University (UniSZA), Gong Badak Campus 21300 Kuala Nerus, Terengganu, Malaysia.

\section{REFERENCES}

Abdullah, A.H. (2018) Daughter of Haji Abdullah Idris, Interview on 06th May 2018, at House Kg. Kubang Pasu, Kota Bharu, 09.30 p.m. - 12.00 p.m.

Abdullah, A.H. (2018) Daughter of Haji Abdullah Idris, Interview on 17th August 2017, at House Kg. Lundang, Kota Bharu, 10.00 p.m. - 12.00 p.m.

Awang, P.H. (2001), Tariqah Ahmadiyyah: History and Development, Intel Multi Media and Publication, Petaling Jaya.

Daud, I.C. (2012), Tokoh-Tokoh Ulama Semenanjung Melayu (1), Kelantan: Majlis Agama Islam Dan Adat Istiadat Melayu Kelantan.

Karrar, A.S. (1991), al-Tariqah al-Idrisiyyah fi al-Sudan, Dar al-Jayl, Beirut.

Mahmud, A.R. (2002), Ikhtisar Sejarah Kelantan, Kota Bharu: Pustaka Aman Press Sdn. Bhd.

Rahman, M.A., granddaughter of Haji Abdus Salam, Interview on 11th Disember 2017, at House Jalan Raja Dewa Telipot, Kota Bharu, 5.00 p.m. - 7.00 p.m.

Sa'ari, C.Z, "Tarekat Ahmadiyyah: Satu Kajian di Negeri Kelantan". Master Theses from University of Malaya, Kuala Lumpur.

Sa'id, A.R.M. (2005), Aurad Tariqah Ahmadiah-Idrisiyyah. (t.tp.t.pt).

Salam, Y.A. (1988), Awrad al-Awlia', Majlis Agama Islam Kelantan.

Sedgwick, M.J.R. (2005), Saints and Sons: The Making and The Remaking of The Rashidi Ahmadi Sufi Order, EJ Brill, Leiden.

Syukur, A.H.A. (1998), Pemikiran Tasawuf Tok Kenali, Pengasuh, bil 553, Julai-Ogos 1998. 